\title{
The Effect of Cognitive and Metacognitive Strategy Training on Intermediate Iranian EFL Learners' Willingness to Communicate
}

Maryam Farzam*

Diako Language School, NO 2, Sharifi Alley, Shriati St, Tehran, Iran

Corresponding Author: Maryam Farzam, E-mail: Maryam_farzam2000@yahoo.com

\section{ARTICLE INFO}

Article history

Received: September 10, 2017

Accepted: November 17, 2017

Published: January 05, 2018

Volume: 7 Issue: 1

Advance access: December 2017

Conflicts of interest: None

Funding: None

\begin{abstract}
The present study aimed at exploring the effects of cognitive and metacognitive strategy training on the WTC of Iranian EFL learners. The participants of the study included 90 Iranian EFL learners at the intermediate level of English language proficiency. They were divided into three groups based on their performance on a general proficiency test. One group received cognitive strategy instruction, another metacognitive strategy instruction and the last one served as the control group. The participants were also tested before and after the treatment in terms of WTC. The results of statistical analysis showed that both cognitive and metacognitive strategy training had a positive effect on the WTC of Iranian EFL learners. It was also revealed that metacognitive and cognitive strategy training had similar effects on the WTC of the participants.
\end{abstract}

Key words: Strategy Training, Cognitive Strategies, Metacognitive Strategies, Willingness to Communicate

\section{INTRODUCTION}

MacIntyre (2007) maintains that the aim of learning an L2 is to acquire linguistic competence along with the knowledge of both the usage as well as use of the linguistic structure. Moreover, more importantly L2 learning is aimed at gaining the ability to use language as a vehicle of communication. Based on the definition given by MacIntyre, Clement, Dornyei, and Noels (2002), language learning is a process thereby an individual is engaged in real communication between people of different languages and various cultural backgrounds. As a matter of fact, the application of L2 for communication is viewed as one of the main purposes of learning English as a foreign language (LEFL). A look at the literature (e.g., Ahmed Mahdi, 2014; Aliakbari, Kamangar, \&Khany, 2016; Bergil, 2016; Fahim, \&Dhamotharan, 2016; Öz, Demirezen, \&Pourfeiz, 2015; Rahbar, Suzani, \&Sajadi, 2016; Valadi, Rezaee, \&Kogani, 2015; Yousefi, \&Kasaian, 2014) indicates that learners with a high level of willing to communicate can take advantage more of the learning opportunities, gaining the ability to become more engaged in learning activities both inside and outside the classrooms.

Therefore, it is very crucial to pinpoint the factors and variables undermining or strengthening the opportunities L2 learners can have to use language communicatively. Such an engagement in authentic communication allows the individuals to pick up language thanks to meaningful interaction and communication (Swain, 2000).As a result, the learners are provided with good chance of learning L2. Willingness to communicate can improve through gaining familiarity and the use of L2 learning strategies.

In the view of Oxford (1990), L2 learning strategies are techniques or actions used by learners to render language learning more effective, autonomous and enjoyable. Learning strategies make it possible for learners to become independent and self-directed. A lot of studies have been carried out on strategies targeting language learning and language use. The results of these studies suggest that strategy-based instruction contributes to the effective use of strategies (Chamot, 2005).Furthermore; there is a generally positive correlation between strategy use and L2 proficiency.

In the view of O'Malley and Chamot (1990), cognitive strategies are defined as the mental processes which individuals apply directly for purpose of extracting, manipulating, internalizing, and automatizing newly leaned points. Oxford (2003) notes that metacognitive strategies (e.g., the identification of one's own learning style options, organizing an L2 task, collecting and arranging materials, organizing a schedule, engaging in monitoring one's mistakes, the assessment of task success, and evaluating the success of any type of learning strategy) are used for planning and managing the learning process.

In the current study the main question is if cognitive and metacognitive strategies, that are strongly related to L2 learning and achievement and also are connected to more confidence, self-esteem and less anxiety, will contribute to Iranian EFL learners' WTC. Although many researchers (Aliakbari, Kamangar, \& Khany, 2016; Fahim, \& Dhamotha- 
ran, 2016; Khajavy, Ghonsooly \& Hosseini Fatemi, 2016; Rahbar, Suzani, \& Sajadi, 2016; Valadi, Rezaee, \& Kogani, 2015; Yousefi, \& Kasaian, 2014) have recently worked on the WTC and language learning strategies (e.g., Ahmadi, \& Mahmoodi, 2012; Alhaisoni, 2012; Chen, 2015; Ghavamnia, Kassaian, \& Dabaghi, 2011; Gürsoy, 2010; Kunasaraphan, 2015; Martínez, Pérez, Luisa, Navarrete, José; De la Blanca de la Paz, 2016; Mashhady, \& Fallah, 2014; Zare, 2012; Zarei, \& Gilanian, 2015), there is a lack of experimental research on the ways of promoting WTC. Therefore, this study tries to fill this gap by training cognitive and metacognitive strategies to the Iranian EFL learners in order to make them more willing to communicate in English.

\section{LITERATURE REVIEW}

L2 learning for a long time was mainly aimed at enhancing linguistic capacity and thoroughly learning the grammar of target language (Brown, 1994). Yet, recently the purpose of teaching English has shifted from gaining mastery over the structure to the capability to use language communicatively. According to Farooq (2015), the notion of communicative competence was introduced in the early 1970s in the context of L2 education. Consequently, the communication dimension of English instruction came to the focus of more attention and research since the 1970s. Furthermore, the ultimate aim of L2 learning is now stated as real communication among individuals of various languages and cultural backgrounds' (MacIntyre, Clement, Dörnyei, \& Noels, 2002).

L2 learning is supposed to happen as an outcome of interactive, meaningful communication in a pragmatic context (Swain \&Lapkin, 2002). As Swain (2000) asserts, when a person takes part in an authentic communication, language use and language learning unfold simultaneously. Actually, language use serves as a mediator when it comes to language learning. Consequently, it is great importance to identify the factors which undermine and improve L2 learners' chances to make use of language in order to communicate and to learn language through engaging in meaningful interaction as well communication (Swain, 2000). This helps L2 learners to improve their performance in the language learning process. Zarrinabadi (2014) claims that past studies conducted on WTC show that teachers' attitude, support, and teaching style are likely to influence learners' willingness to communicate.

In recent years, the domain of L2 teaching and learning has focused on meaningful communication (Brown, 2007). As a result, the notion of students' willingness to take part in communication is considered more essential than ever within the context of L2 learning studies (Matsuoka \& Evans, 2005). In the same veins, an increasing number of investigations (e.g., Wen \& Clement 2003; Cao \& Philip 2006; Alemi, Tajeddin, \&Mesbah, 2013) dealt with the different variables that may impact L2 learners' wiliness to communicate. Despite an increasing interest in WTC, how instructors can influence learners' WTC via the instruction of L2 learning strategies has not been completely investigated.

Oxford and Scarcella (1992) have defined learning strategies as certain measures, actions, steps, or techniques (e.g., looking for conversation partners, or pushing oneself to deal with a difficult language task. These strategies are used by learners to improve their own learning. Based on the typology proposed by O'Malley and Chamot (1990), two major kinds of L2 learning strategies are cognitive and metacognitive strategies. As mental process, cognitive strategies are directly employed by L2 learner in order to extract, modify, internalize, and automatize newly learned points. In contrast, metacognitive strategies are not direct mental operations. They are indirect strategies used to organize, regulate, and monitor one's learning.

Oxford (2003) asserts that cognitive strategies allows the individuals to directly modify the language material (e.g., analyzing, self-directing, logical concluding, summarizing, arranging, rewording information, outlining, rehearsing in authentic settings, and practicing structural elements and sounds formally). A study conducted by Oxford and Ehrman (1995) focused on cognitive strategies and their contribution to language proficiency. Brown (2007) asserts that cognitive strategies are limited to certain learning tasks, with direct modifications of the learning material itself.

Drawing on Academic Spoken English Strategies Survey (ASESS) for non-native English speaking graduate students (Schroeder, 2016) three cognitive speaking strategies include, rehearsing before presenting in class; Reading aloud materials to practice speaking in English and putting the stress on important words (speak them louder or for longer time).

According to Oxford (2003), metacognitive strategies (e.g., pinpointing one's preferences for learning style, planning for an L2 task, collecting and ordering materials, developing a schedule, monitoring one's mistakes, and assessing task accomplishment, and assessing the efficacy of any kind of learning strategy) are used for planning the learning process overall. Metacognition is concerned with the knowledge and control exerted by individuals over their cognitive processes. As for reading, metacognitive awareness and metacognitive regulation or control are usually discussed (Rasouli, et al., 2013).

A study conducted by Purpura (1999) indicated that in the case of native English speakers who are engaged in learning foreign languages, metacognitive strategies influence cognitive strategy use positively. This provides evidence that metacognitive strategy use has an executive function over cognitive strategy use in task completion. EFL learners' education in different countries shows that metacognitive strategies serve as reliable predictors of second language proficiency (Dreyer \& Oxford, 1996).

The application of metacognitive strategies sets in motion one's thinking, resulting in the improved performance in teach (Anderson, 2002). The study conducted by Vandergrift (1997) showed that metacognitive strategies including analyzing can improve listening processes required. They are able to make appropriate predictions, monitoring their comprehension. According to Goh (2008), metacognitive strategy training enhances learners' confidence, making them less anxious in the listening process.

Drawing on Academic Spoken English Strategies Survey (ASESS) for non-native English speaking graduate students (Schroeder, 2016) three metacognitive speaking strategies 
include, Paying attention to how people explain ideas in English, Thinking about how to make your message clear and precise before speaking and Building upon what classmates have said and joining in the class discussion.

Given the importance of WTC and language learning strategies, the current study aimed at investigating the effect of cognitive and metacognitive strategy training on intermediate Iranian EFL learners' willingness to communicate. To this aim, the following research questions were formulated:

\section{RESEARCH QUESTIONS}

Q1: Does cognitive strategy training significantly affect Intermediate Iranian EFL learners' WTC?

Q2: Does metacognitive strategy training significantly affect Intermediate Iranian EFL learners' WTC?

Q3: Are there any significant differences between the effect of cognitive and metacognitive strategy instruction on the WTC of Iranian EFL learners?

\section{METHOD}

\section{Participants}

The participants of the current study were 120 female foreign language learners at the intermediate level of language proficiency studying English at DIAKO Language Academy. They were selected based on convenience sampling method for availability and manageability reasons. In terms of age they were within the age range of 18 to 35 and included only female students. The 120 participants took OPT the scores of which were used to select only those learners whose scores fell within the range of $+/$ - one standard deviation from the mean. The selected 90 learners were randomly assigned into three groups, i.e. cognitive, metacognitive and control group.

\section{Data Collection Instruments}

\section{Oxford placement test (OPT)}

As a proficiency test, OPT contains 100 items which tests the English learners' proficiency in 45 minutes. The participants' scores show their level of language proficiency from beginners to advanced level as follows:
$00-20$
Elementary
21-35
Pre-intermediate
36-60
Intermediate
61-85
Upper-Intermediate
$86-100$
Advanced

\section{WTC Questionnaire}

To measure learners' WTC levels, a Likert-type questionnaire developed by MacIntyre et al. (2001) was distributed among the participants. The questionnaire included 25 items relevant to the factors contributing to WTC in learning a second language. The questionnaire follows a Likert-type scale ranging from strongly disagree (1) to strongly agree (5). The learners were asked to indicate their answers to the items across the continuum. Cronbach's alpha was used to estimate the reliability of the questionnaire on a pilot sample of 30 language learners. The pilot sample included language learners at intermediate level of language proficiency and within the age rage of the actual participants.

\section{Speaking strategy list}

Drawing on Academic Spoken English Strategies Survey (ASESS) for non-native English speaking graduate students (Schroeder, 2016) a selection of 3 cognitive and 3 metacognitive speaking strategies were chosen for instruction. These strategies are as follows:

Metacognitive

Paying attention to how people explain ideas in English

Thinking about how to make your message clear and precise before speaking

Building upon what classmates have said and joining in the class discussion.

Cognitive

Rehearsing before presenting in class

Reading aloud materials to practice speaking in English

Putting the stress on important words (speak them louder or for longer time).

\section{Data Collection Procedure}

120 EFL learners at the intermediate level took OPT the scores of which were drawn on to choose a homogeneous sample of 90 participants who were randomly assigned into two experimental and a control group. Afterwards, the participants in the three groups were asked to complete the WTC questionnaire. Their WTC scores were used as indices of their WTC prior to the main study.

Then the treatment sessions began as follows:

Both experimental groups received strategy instruction based on Strategies Program for Effective Learning and Thinking (S.P.E.L.T). The program was proposed by Mulcahy, Marfo, Peat, and Andrews (1987) which included three phases for strategy instruction. Based on Mulcahy et al. (1987), first the target strategies and their application were explained to the students. They were also informed about the importance and significant of the speaking strategies to improve their speaking. To this end the teacher employed motivating talk and exemplifications as proposed by Mulcahy et al. (1987). Students were encouraged to talk about their speaking and communication problems so that they notice the need for strategy learning to deal with their speaking and communication challenges. Next, based on the target strategies, the teacher presented some scenarios and thought aloud her thought process and the way the target strategies could help her in the hypothetical situations. Finally, students practiced the strategies with the help of the instructor.

The whole course of the study lasted for 12 sessions out of which 10 sessions were for the treatment. In each session, the teacher wrote the target strategies on the board and during the class, students were asked to focus on the strategies when needed. In cases strategies needed to be used before the following classes, students were asked to use the strategies when preparing for the upcoming classes. It 
needs to be noted that one group practiced cognitive strategies while the other one practiced metacognitive strategies. The participants in the control group went through the usual classes without specific focus on strategies. In the control group, the participants did not receive any instruction concerning the cognitive or metacognitive strategies and just followed the regular syllabus of the institute.

The treatment lasted for 10 sessions and each session was one hour and a half. After the treatment sessions, the WTC questionnaire was again administered to the participants of the three groups. The schematic plan for the whole course of the study is represented in Table 1 .

\section{Design}

The study adopted a quasi-experimental model using pretest-posttest design to explore the effect of cognitive and metacognitive instruction on the participants' WTC before and after the treatment. The schematic representation is as follows:

G1 (Pre) - T- Post

G2 (Pre) - T- Post

In the scheme above, $G$ represents group, Pre represents pretest, T represents treatment, and Post represents posttest.

\section{RESULTS AND DISCUSSION}

\section{Language Proficiency of the Students}

As stated in chapter three, initially 120 language learners at intermediate level were selected based on their availability. Intermediate learners took the OPT so that their OPT scores could be used as a criteria to single out those participants who had the closest scores to the mean score. In other words, the attempt aimed at selecting only participants with homogenized English language proficiency. Table 2 shows the descriptive statistics of the 120 intermediate language learners.

Table 2 shows that students had a mean score of 65.82 $(\mathrm{SD}=9.82)$ on OPT. Table 2 illustrates the distribution of OPT scores of the students.

As seen in Figure 1 the distribution of OPT scores are close to normal distribution which means that mean score can be good indicator of central points of distributions. To choose those students with homogenized language proficiency, students whose OPT scores fell within the range of mean score \pm 1 SD were extracted from the pool of 120 language learners. Table 3 shows the descriptive statistics of those students with scores between mean score \pm 1 SD.

According to Table 3, mean score of students is 65.64 $(\mathrm{SD}=5.85)$. Mean scores of the students did not change a lot from that of initial pool of students but SD had almost half

Table 1. The schematic plan for the whole course of the study

\begin{tabular}{ll}
\hline Session & Description \\
\hline 1 & OPT+WTC Pretest \\
2 to 11 & Treatment \\
12 & WTC Posttest \\
\hline
\end{tabular}

reduced which is an indication of more homogenized language proficiency scores among the intermediate language learners. After establishing the homogeneity of students they were randomly assigned to three groups to serve as two experimental groups and one control group.

\section{Homogeneity of the Students in Terms of WTC}

Before starting the experiment, it was also necessary to establish that the group serving as control group (hereafter called control group) and the group receiving treatment were homogeneous in terms of initial WTC. As stated earlier, participants of the study completed WTC questionnaire and the obtained scores were used to examine for any possible differences between the groups. This was done through employing the statistical method of ANOVA. Table 3 shows descriptive statistics and Table 4 shows the result of ANOVA between the groups on initial WTC scores.

As seen in Table 4 metacognitive group had a mean score of $63.10(\mathrm{SD}=4.16)$, cognitive group had a mean score of 64.10 ( $\mathrm{SD}=4.38)$, and control group had a mean score of $63.50(\mathrm{SD}=5.23)$. Although the groups had similar mean scores, ANOVA was run between the groups to further make sure they are not significantly different from each other or in other words they are homogeneous in terms of WTC.

According to results of Levene's test of equality of variances (see Table 5), the groups had equal variances in WTC scores $(p>0.05)$ which made the use of ANOVA legitimate. ANOVA indicated that that there was no significant difference between groups in terms of initial WTC $(\mathrm{F}=0.35$, $\mathrm{P}>0.05$ ) or in other words they were homogeneous in terms of WTC.

\section{Reliability of WTC}

One of the concerns of the study was obtaining reliable data which was largely dependent on the reliability of the data collection instrument. The reliability of WTC was estimated through Cronbach' Alpha internal consistency measure on a pilot sample of 30 students before starting the main study. Table 6 shows the results of Cronbach's Alpha analysis on the WTC scores used in the pilot study.

As seen in the Table 6 the mean score of the pilot sample is $63.70(\mathrm{SD}=4.32)$, for WTC. Alpha values for WTC questionnaire was found 0.73 which is an acceptable index of reliability.

\section{Investigating the First Research Question}

The first research question was about the effect of cognitive strategy training on Intermediate Iranian EFL learners' WTC. The current study followed a pretest posttest design which allowed the comparison of WTC before and after cognitive strategy training. Table 7 compares the WTC scores between pretest and posttest of the cognitive strategy group.

Based on the descriptive analysis, cognitive group had a mean score of $64.10(\mathrm{SD}=4.38)$ before treatment and a mean score of $65.86(\mathrm{SD}=4.38)$ after treatment. To statistically determine the significance or insignificance of difference in 
Table 2. Descriptive statistics of the 120 intermediate language learners in terms of OPT scores

\begin{tabular}{lccccc}
\hline & N & Minimum & Maximum & Mean & Standard deviation \\
\hline OPT & 120 & 44.00 & 89.00 & 65.8250 & 9.82679 \\
Valid N (listwise) & 120 & & & & \\
\hline
\end{tabular}

Table 3. Descriptive statistics of those students with scores between mean score \pm 1 SD

\begin{tabular}{lccccc}
\hline & N & Minimum & Maximum & Mean & Standard deviation \\
\hline OPT Homogenized & 90 & 56.00 & 76.00 & 65.6444 & 5.85655 \\
Valid N (listwise) & 90 & & & & \\
\hline
\end{tabular}

Table 4. Descriptive statistics of initial WTC for control and experimental groups

\begin{tabular}{|c|c|c|c|c|c|c|c|c|}
\hline & \multirow[t]{2}{*}{$\mathbf{N}$} & \multirow[t]{2}{*}{ Mean } & \multirow[t]{2}{*}{$\begin{array}{l}\text { Standard } \\
\text { deviation }\end{array}$} & \multirow[t]{2}{*}{$\begin{array}{l}\text { Standard } \\
\text { error }\end{array}$} & \multicolumn{2}{|c|}{$\begin{array}{l}\text { 95\% confidence interval for } \\
\text { mean }\end{array}$} & \multirow[t]{2}{*}{ Minimum } & \multirow[t]{2}{*}{ Maximum } \\
\hline & & & & & Lower bound & Upper bound & & \\
\hline Metacognitive & 30 & 63.1000 & 4.16347 & 0.76014 & 61.5453 & 64.6547 & 55.00 & 71.00 \\
\hline Cognitive & 30 & 64.1000 & 4.38139 & 0.79993 & 62.4640 & 65.7360 & 56.00 & 75.00 \\
\hline Control & 30 & 63.5000 & 5.23088 & 0.95502 & 61.5468 & 65.4532 & 55.00 & 71.00 \\
\hline Total & 90 & 63.5667 & 4.58147 & 0.48293 & 62.6071 & 64.5262 & 55.00 & 75.00 \\
\hline
\end{tabular}

Table 5. Results of ANOVA between the groups on OPT scores

\begin{tabular}{|c|c|c|c|c|c|c|c|c|c|}
\hline & Sum of squares & df & Mean square & $\mathbf{F}$ & Sig. & Levene statistic & df1 & df2 & Sig. \\
\hline Between groups & 15.200 & 2 & 7.600 & 0.357 & 0.701 & 1.908 & 2 & 87 & 0.155 \\
\hline Within groups & 1852.900 & 87 & 21.298 & & & & & & \\
\hline Total & 1868.100 & 89 & & & & & & & \\
\hline
\end{tabular}

Table 6 Results of Cronbach's alpha analysis of WTC questionnaire piloted on 30 students

\begin{tabular}{lccccccc}
\hline & N & Minimum & Maximum & Mean & Standard deviation & Alpha & N of items \\
\hline WTC pilot & 30 & 56.00 & 75.00 & 63.7000 & 4.32435 & 0.733 & 25 \\
Valid N (listwise) & 30 & & & & & & \\
\hline
\end{tabular}

Table 7. WTC scores between pretest and posttest of the cognitive strategy group

\begin{tabular}{ccccc}
\hline & Mean & $\mathbf{N}$ & $\begin{array}{c}\text { Standard } \\
\text { deviation }\end{array}$ & $\begin{array}{c}\text { Standard } \\
\text { error mean }\end{array}$ \\
\hline Pair 1 & & & & \\
Pre & 64.1000 & 30 & 4.38139 & 0.79993 \\
Post & 65.8667 & 30 & 4.37653 & 0.79904 \\
\hline
\end{tabular}

WTC mean scores, paired samples t-test was run on the pretest and posttest scores.

Paired sample t-test is a parametric test and accordingly normality of WTC scores was checked through Kolmogorov Smirnov test of normality. As seen in Table 8, both pretest and posttest WTC scores are normally distributed $(\mathrm{P}>0.05)$ which made the use of paired samples t-test legitimate. According to the results of paired sample t-test there was significant difference between the WTC pretest and posttest scores $(\mathrm{t}=13.29, \mathrm{P} \leq 0.05)$ which suggested that cognitive strategy training had positive effect on the WTC of the students.
In addition to the comparison of pretest and posttest, comparison between posttests of cognitive strategy and control group was also performed to make sure about the superiority of cognitive strategy training over conventional instruction in terms of contribution to WTC. Table 9 shows the result of independent samples t-test between WTC posttest of cognitive strategy and control groups.

As seen in Table 9 Kolmogorov Smirnov test of normality shows that WTC posttest scores in cognitive and control groups were normally distributed $(\mathrm{P}>0.05)$. In addition, Levene's test of equality of variances indicated that both sets of scores had equal variances $(\mathrm{F}=1.35, \mathrm{P}>0.05)$. According to the results of independent samples t-test (Table 9), it was found that there was a significant difference between WTC posttest scores of cognitive strategy and control groups $(\mathrm{t}=2.33, \mathrm{p} \leq 0.05)$. Therefore, it can be claimed that cognitive strategy training had better effect on the WTC of the students.

\section{Investigating the Second Research Question}

The second research question was about the effect of metacognitive strategy training significantly on Intermediate 
Table 8. Results of Kolmogorov-Smirnov a between pretest and posttest WTC scores in cognitive strategy group

\begin{tabular}{|c|c|c|c|c|c|c|c|c|c|}
\hline & \multicolumn{3}{|c|}{ Paired differences } & \multirow[t]{2}{*}{$\mathbf{t}$} & \multirow[t]{2}{*}{ df } & \multirow[t]{2}{*}{ Sig. (2-tailed) } & \multicolumn{3}{|c|}{ Kolmogorov-Smirnov ${ }^{\mathrm{a}}$} \\
\hline & Mean & $\begin{array}{l}\text { Standard } \\
\text { deviation }\end{array}$ & $\begin{array}{l}\text { Standard } \\
\text { error mean }\end{array}$ & & & & Statistic & df & Sig. \\
\hline Pair 1 & -1.76667 & 0.72793 & 0.13290 & -13.293 & 29 & 0.000 & 0.085 & 30 & $0.200 *$ \\
\hline Pre -Post & & & & & & & 0.078 & 30 & $0.200 *$ \\
\hline
\end{tabular}

Table 9. Results of Levene's test between WTC posttest of cognitive strategy and control groups

\begin{tabular}{|c|c|c|c|c|c|c|c|c|c|}
\hline & \multicolumn{2}{|c|}{$\begin{array}{l}\text { Levene's test } \\
\text { for equality } \\
\text { of variances }\end{array}$} & \multicolumn{3}{|c|}{ t-test for equality of means } & \multicolumn{4}{|c|}{ Test of normality } \\
\hline & \multirow[t]{2}{*}{$\mathbf{F}$} & \multirow[t]{2}{*}{ Sig. } & \multirow[t]{2}{*}{$\mathbf{t}$} & \multirow[t]{2}{*}{ df } & \multirow[t]{2}{*}{ Sig. (2-tailed) } & \multirow[t]{2}{*}{ Group } & \multicolumn{3}{|c|}{ Kolmogorov-Smirnov ${ }^{\mathrm{a}}$} \\
\hline & & & & & & & Statistic & df & Sig. \\
\hline \multicolumn{10}{|l|}{$\begin{array}{l}\text { Willingness to communicate } \\
\text { posttest (dependent variable) }\end{array}$} \\
\hline Equal variances assumed & 1.355 & 0.249 & 2.337 & 58 & 0.023 & Cognitive & 0.078 & 30 & $0.200^{*}$ \\
\hline Equal variances not assumed & & & 2.337 & 57.021 & 0.023 & Control & 0.110 & 30 & $0.200 *$ \\
\hline
\end{tabular}

Iranian EFL learners' WTC. In order to find the answer to this research question, the same procedure of first research question was repeated. Table 10 compares the WTC scores between pretest and posttest of the metacognitive strategy group.

Based on the descriptive analysis, metacognitive group had a mean score of $63.10(\mathrm{SD}=4.16)$ before treatment and a mean score of $67.80(\mathrm{SD}=4.00)$ after treatment. To statistically determine the significance or non-significance of difference in WTC mean scores, paired samples t-test was run on the pretest and posttest scores.

As seen in Table 11, both pretest and posttest WTC scores are normally distributed $(\mathrm{P}>0.05)$ which made the use of paired samples t-test legitimate. According to the results of paired sample t-test (Table 10) there was a significant difference between the WTC pretest and posttest scores $(\mathrm{t}=22.40$, $\mathrm{P} \leq 0.05$ ) which suggests that metacognitive strategy training had positive effect on the WTC of the students. Table 12 shows the result of independent samples t-test between WTC posttest of metacognitive strategy and control groups.

As seen in Table 12 Kolmogorov Smirnov test of normality shows that WTC posttest scores in metacognitive and control groups were normally distributed $(\mathrm{P}>0.05)$. In addition, Levene's test of equality of variances indicated that both sets of scores had equal variances $(\mathrm{F}=2.43, \mathrm{P}>0.05)$. According to the results of independent samples t-test (Table 12), it was found that there was a significant difference between WTC posttest scores of metacognitive strategy and control groups $(\mathrm{t}=4.08, \mathrm{p} \leq 0.05)$. Therefore, it can be claimed that metacognitive strategy training had better effect on the WTC of the students.

\section{Investigating the Third Research Question}

The third research question was whether there were any significant differences between the effect of cognitive and metacognitive strategy instruction on the WTC of Iranian
Table 10. WTC scores between pretest and posttest of the metacognitive strategy group

\begin{tabular}{ccccc}
\hline & Mean & N & $\begin{array}{c}\text { Standard } \\
\text { deviation }\end{array}$ & $\begin{array}{c}\text { Standard } \\
\text { error mean }\end{array}$ \\
\hline Pair 1 & & & & \\
Pre & 63.1000 & 30 & 4.16347 & 0.76014 \\
Post & 67.8000 & 30 & 4.00345 & 0.73093 \\
\hline
\end{tabular}

EFL learners. The effect of cognitive and metacognitive strategy training was measured by WTC posttest and since the two groups were equal in terms of WTC at pretest any difference in the effect of cognitive strategy and metacognitive strategy could be easily traced through comparing the WTC posttest between the two groups. Table 13 shows the descriptive statistics of the two groups at posttest.

In WTC posttest, metacognitive group had a mean score of $67.80(\mathrm{SD}=4.00)$ and cognitive group had a mean score of $65.86(\mathrm{SD}=4.37)$. The two groups did not differ much in mean scores, however: to better decide on the difference of the means scores, the mean scores were compared using independent samples t-test.

According to Table 14 Levene's test of equality of variances indicated that both sets of scores had equal variances $(\mathrm{F}=0.9, \mathrm{P}>0.05)$. According to the results of independent samples t-test, it was found that there was no significant difference between WTC posttest scores of metacognitive strategy and cognitive strategy groups $(\mathrm{t}=1.78, \mathrm{p}>0.05)$. Therefore, it can be claimed that metacognitive and cognitive strategy training had similar effects on the WTC of the students.

\section{DISCUSSION}

The current study aimed at examining the effect of cognitive and metacognitive strategy training on the willingness to communicate (WTC) of Iranian EFL learners. Participants 
Table 11. Results of Kolmogorov-Smirnova between pretest and posttest WTC scores in metacognitive strategy group

\begin{tabular}{|c|c|c|c|c|c|c|c|c|c|}
\hline & \multicolumn{3}{|c|}{ Paired differences } & \multirow[t]{2}{*}{$\mathbf{t}$} & \multirow[t]{2}{*}{ df } & \multirow[t]{2}{*}{ Sig. (2-tailed) } & \multicolumn{3}{|c|}{ Kolmogorov-Smirnov ${ }^{\mathrm{a}}$} \\
\hline & Mean & $\begin{array}{l}\text { Standard } \\
\text { deviation }\end{array}$ & $\begin{array}{c}\text { Standard error } \\
\text { mean }\end{array}$ & & & & Statistic & df & Sig. \\
\hline \multicolumn{10}{|l|}{ Pair 1} \\
\hline \multirow[t]{2}{*}{ Pre -Post } & -4.70000 & 1.14921 & 0.20982 & -22.401 & 29 & 0.000 & 0.086 & 30 & $0.200 *$ \\
\hline & & & & & & & 0.091 & 30 & $0.200^{*}$ \\
\hline
\end{tabular}

Table 12. Results of Levene's test between WTC posttest of metacognitive strategy and control groups

\begin{tabular}{|c|c|c|c|c|c|c|c|c|c|}
\hline & \multicolumn{2}{|c|}{$\begin{array}{l}\text { Levene's test } \\
\text { for equality } \\
\text { of variances }\end{array}$} & \multicolumn{3}{|c|}{ t-test for equality of means } & \multicolumn{4}{|c|}{ Test of normality } \\
\hline & \multirow[t]{2}{*}{$\mathbf{F}$} & \multirow[t]{2}{*}{ Sig. } & \multirow[t]{2}{*}{$\mathbf{t}$} & \multirow[t]{2}{*}{ df } & \multirow{2}{*}{$\begin{array}{c}\text { Sig. } \\
\text { (2-tailed) }\end{array}$} & \multirow[t]{2}{*}{ Group } & \multicolumn{3}{|c|}{ Kolmogorov-Smirnov ${ }^{a}$} \\
\hline & & & & & & & Statistic & df & Sig. \\
\hline \multicolumn{10}{|l|}{$\begin{array}{l}\text { Willingness to communicate } \\
\text { posttest (dependent variable) }\end{array}$} \\
\hline Equal variances assumed & 2.431 & 0.124 & 4.080 & 58 & 0.000 & Metacognitive & 0.091 & 30 & $0.200 *$ \\
\hline $\begin{array}{l}\text { Equal variances not } \\
\text { assumed }\end{array}$ & & & 4.080 & 55.384 & 0.000 & Control & 0.110 & 30 & $0.200 *$ \\
\hline
\end{tabular}

Table 13. Descriptive statistics of the final WTC

\begin{tabular}{llllcc}
\hline & Groups & N & Mean & $\begin{array}{c}\text { Standard } \\
\text { deviation }\end{array}$ & $\begin{array}{c}\text { Standard } \\
\text { error mean }\end{array}$ \\
\hline Willingness to communicate posttest (dependent variable) & Metacognitive & 30 & 67.8000 & 4.00345 & 0.73093 \\
& Cognitive & 30 & 65.8667 & 4.37653 & 0.79904 \\
\hline
\end{tabular}

Table 14. Results of independent samples test between cognitive and metacognitive strategy group in WTC posttest

\begin{tabular}{|c|c|c|c|c|c|}
\hline & \multicolumn{2}{|c|}{$\begin{array}{c}\text { Levene's test } \\
\text { for equality of } \\
\text { variances }\end{array}$} & \multicolumn{3}{|c|}{ t-test for equality of means } \\
\hline & $\mathbf{F}$ & Sig. & $\mathbf{t}$ & df & Sig. (2-tailed) \\
\hline \multicolumn{6}{|c|}{ Willingness to communicate posttest (dependent variable) } \\
\hline Equal variances assumed & 0.090 & 0.765 & 1.785 & 58 & 0.079 \\
\hline Equal variances not assumed & & & 1.785 & 57.546 & 0.079 \\
\hline
\end{tabular}

of the study completed WTC questionnaire before and after receiving cognitive and metacognitive strategy training. The strategies targeted the speaking strategies as the focus of the study was on willingness to communicate. The participants were grouped into three groups; cognitive strategy group, metacognitive strategy group, and control group. Results of data analysis showed that both cognitive and metacognitive strategy training increased WTC of the students significantly. The participants who received cognitive and metacognitive strategy training also outperformed the control group in the measure of WTC further supporting the efficacy of cognitive and metacognitive strategy training. In this section the results are discussed in light of theories and empirical studies.

This study showed that both cognitive and metacognitive strategy training increased EFL learners' WTC significantly. This was in line with the findings of other studies which found strategic instruction beneficial in dealing with language related problems (Dreyer \& Oxford, 1996; Griffiths,
2003; Kyungsim \& Leavell, 2006; Nakatani, 2005; Oxford, 1995; Park, 1997; Yang, 2009). Rashtchi and Khani (2010) also implemented metacognitive strategy instruction with 56 participants in a language school in to improve their oral proficiency. The results indicated that the experimental group outperformed the control group leading to the conclusion that instruction on metacognitive strategy use prior to oral tasks had a significantly higher impact on EFL learners' oral proficiency and metacognitive strategy use as compared to the only warm-up preceding oral tasks.

However, the findings of the current study were in contrast with Abbasian's (2015) who explored the correlation between metacognitive strategy use and WTC of 95 Iranian EFL learners. He found out that metacognitive strategy use was not significantly related to WTC of Iranian EFL learners. He did not propose any explanation for such lack of relationship and just pointed to the idiosyncratic nature of context of learning and teaching environment. 
In order to explain the positive effects of cognitive and metacognitive strategy training on WTC of students, it should be noted that there is enough background in literature regarding the benefits of strategy use in dealing with language related problems (Dreyer \& Oxford, 1996; Green and Griffiths, 2003; Kyungsim \& Leavell, 2006; Oxford, 1995; Park, 1997; Yang, 2009). For instance in a study by Nakatani (2005), 62 female underwent metacognitive strategy training for 12 weeks and the effects of the training were examined through 3 types of data collection: the participants' test scores in pretest and posttest, analyzing data from the tests, and retrospective protocol. The results revealed that strategy training group significantly enhanced oral proficiency of the experimental group.

In addition it can be argued that one of the obstacles to communication is the lack of confidence as the studies have pointed to the role of confidence and anxiety in demotivating EFL learners. For instance, Chang and Cho (2003) explored the factors involved in demotivating English language learning among high school students in Taiwan. Based on all the essays they were asked to write, eight factors were indicated as the sources of demotivation. They were (1) difficulties in learning; (2) threats to self-worth; (3) boring teaching; (4) weak teacher-student relationship; (5) punishments; (6) student anxiety, both general and language-specific; (7) lack of self-determination; and (8) weak classroom management. Falout and Maruyama (2004) identified six categories of demotivating factors: a) Teachers, b) Courses, c) Attitudes towards English speaking people, d) Attitude toward English, e) Self-confidence, and f) Attitude of group members. In their study, Sakai and Kikuchi (2009), came up with a list of five factors of demotivation in high school EFL learners: (1) course content and material, (2) teacher competence and teaching style, (3) inadequate school facilities, (4) lack of intrinsic motivation, and (5) test scores. Therefore, it can be explained that cognitive and metacognitive strategy training boosted learners' confidence through providing strategies to overcome some of the communication challenges.

The cognitive strategies dealt with direct strategies for practicing and learning speaking and it is quite acceptable to expect positive result from cognitive strategy training. Cognitive strategies are more directly related to individual learning tasks and entail direct manipulation or transformation of the learning materials (O'Malley et al., 1985). On the other hand, metacognition includes awareness and control of planning, monitoring, repairing, revising, summarizing, and evaluating. O'Malley et al. (1985) stated that metacognitive strategies involve thinking about the learning process, planning for learning, monitoring of comprehension or production while it is taking place, as self-evaluation of learning after the learning activity is completed. According to Oxford (1990) through using metacognitive strategies, students are allowed to assess their own learning pattern and progress. Therefore, it is quite acceptable to expect positive effect of metacognitive strategies on WTC of learners as they can be better prepared for speaking challenges.

\section{REFERENCES}

Abbasian, G. (2015). The relationship between metacognitive strategy use, good language learners, and Iranian EFL learners's willingness to communicate. Linguistic and Literary Broad Research and Innovation, 4(1), 27-45.

Ahmadi, A., \& Mahmoodi, S. (2012). Language learning strategy use and instruction for the Iranian junior high school EFL learners. RALS, 3 (2), 107-134.

Ahmed Mahdi, D. (2014). Willingness to Communicate in English: A Case Study of EFL Students at King Khalid University. English Language Teaching, 7(7), 17-25.

Alemi, M., Tajeddin, Z., \& Mesbah, Z. (2013). Willingness to communicate in L2 English: impact of learner variables. Journal of Research in Applied Linguistics, 4(1), 42-61.

Alhaisoni, E. (2012). "Language learning strategy use of Saudi EFL student's inan intensive English learning context". Asian Social Science, 8(13), 115-127

Aliakbari, M., Kamangar, M., \& Khany, R. (2016). Willingness to Communicate in English among Iranian EFL Students. English Language Teaching, 9(5), 33-44.

Anderson, N. J. (2002). The role of metacognition in second language teaching and learning. Washington, DC: Center for Applied Linguistics. ERIC Clearing house on Languages and Linguistics.

Bandarabbasi, R., \& Karbalaei, A. (2013). The study of the relationship between multiple intelligences and learning strategies among Iranian EFL learners. European Online Journal of Natural and Social Sciences, 2(2), 143-149.

Bergil, A. S. (2016). The Influence of Willingness to Communicate on Overall Speaking Skills among EFL Learners. Procedia - Social and Behavioral Sciences, 232(2), $177-187$.

Brown, H. D. (1994). Principles of language learning and teaching. Englewood cliffs, New Jersey: Prentice-Hall.

Brown, H. D. (2007). Principles of language learning and teaching $\left(5^{\text {th }}\right.$ ed.). White Plains, NY: Pearson Education.

Cao, Y., \& Philip, J. (2006). Interactional context and willingness to communicate: A comparison of behavior in whole class, group and dyadic interaction. System, 34(3), 480-493.

Chamot, A. U. (2005). Language learning strategy instruction: Current issues and research. Annual Review of Applied Linguistics, 25(1), 112-130.

Chang, S. M., \& Cho, C. H. (2003). Demotivating factors in foreign language learning. Selected Papers from the Twelfth International Symposium on English Teaching. (pp. 257-264). Taipei: Crane Publishing.

Chen, H. I. (2015). Learner autonomy and the use of language learning strategies in a Taiwanese Junior high school. Journal of Studies in Education, 5(1), 52-64.

Dreyer, C., \& Oxford, R. (1996). Prediction of ESL proficiency among Afrikaans-speakers in South Africa. In R. Oxford (Ed.), Language learning strategies around the World: Cross-cultural Perspectives. Second Language Teaching and Curriculum Center, University of Hawaii: Honolulu. 
Fahim, A., \& Dhamotharan, M. (2016). Willingness to Communicate in English among Trainee Teachers in a Malaysian Private University. Journal of Social Sciences, 12(2), 105-112.

Falout, J., \& Maruyama, M. (2004). A Comparative Study of Proficiency and Learner Demotivation. The Language Teacher, 28(8), 3-9.

Farooq, F. U. (2015). Creating a communicative language teaching environment for improving students' communicative competence at EFL/EAP University Level. International Education Studies, 8(4), 179-191.

Ghavamnia, M., Kassaian, Z., \& Dabaghi, A. (2011). The relationship between language learning strategies, language learning beliefs, motivation, and proficiency: A study of EFL learners in Iran. Journal of Language Teaching and Research, 2(5), 1156-1161.

Goh, C. (2008). Metacognitive instruction for second language listening development: Theory, practice and Research implications. RELC Journal, 39(2), 188-213.

Griffiths, C. (2003). Patterns of language learning strategy use. System, 31(4), 367-383.

Gürsoy, E. (2010). Investigating language learning strategies of EFL children for the development of a taxonomy. English Language Teaching, 3(3), 164-175.

Khajavy, Gh. H., Ghonsooly, B., \& Hosseini Fatemi, A. (2016). Willingness to Communicate in English: A Microsystem Model in the Iranian EFL Classroom Context. TESOL QUARTERLY, 50(1), 154-180.

Kunasaraphan, K. (2015). English learning strategy and proficiency level of the first year students. Procedia - Social and Behavioral Sciences, 197(19), 1853 - 1858.

Kyungsim, H., \& Leavell, A. (2006). Language learning strategy use of ESL students in an intensive English learning context. System, 34(4), 399-415.

Macintyre, P. D. (2007). Willingness to communicate in the second language: Understanding the decision to speak as a volitional process. The Modern Language Journal, 91(5), 564-576.

MacIntyre, P. D., Baker, S. C., Clement, R., \& Conrod, S. (2001). Willingness to communicate, social support, and language-learning orientations of immersion students. Studies on Second Language Acquisition, 23(3), 369-388.

MacIntyre, P., Clement, R., Dornyei, Z., \& Noels, K. (2002). Conceptualizing willingness to communicate in a L2: A situational model of L 2 confidence and affiliation. The Modern Language Journal, 82(6), 545-562.

Martínez, R. J. J. Pérez, V., Luisa, M., Navarrete, H., José; De la Blanca de la Paz, S. (2016). Language learning strategy use by Spanish EFL students: the effect of proficiency level, gender, and motivation. Revista de Investigación Educativa, 34(1), 133-149.

Mashhady, H., \& Fallah, N. (2014). The relationship between language learning strategies, field of study, gender, and language proficiency. IJRELT, 2(2), 46-61.

Matsuoka, R., \& Evans, D. R. (2005). Willingness to communicate in the second language. Journal of Nurse Studies NCNJ, 4(1), 3-12.
Mulcahy, R., Marfo, K., Peat, D., \& Andrews, J. (1987). Strategies program for effective learning and thinking: A teachers manual. Alberta. University of Alberta.

Nakatani, Y. (2005). The effect of awareness-raising training on oral communication strategy use. The Modern Language Journal, 99(1), 176-192.

O’Malley, J., Chamot, A., Stewner-Manzanares, G., Russo, R., \& Kupper, L. (1985). Learning strategy applications with students of English as a second language. TESOL Quarterly, 19, 557-584.

O’Malley, J., \& Chamot, A. (1990). Learning strategies in second language acquisition. Cambridge: Cambridge University Press.

Oxford, R. (1990). Language learning strategies: What every teacher should know. Boston: Heinle \& Heinle.

Oxford, R. L. (1995). Instructional implications of gender differences in second/foreign language learning styles and strategies. Applied Language Learning 4, pp. 65-94.

Oxford, R. L. (2003). Language learning styles and strategies: An overview. Learning Styles \& Strategies/Oxford, GALA. Retrieved from http://web.ntpu.edu.tw/ language/workshop/read2.pdf

Oxford, R. L., \& Ehrman, M. E. (1995). Adults' language learning strategies in an intensive foreign language program in the United States. System, 23(3), 359-386.

Oxford, R., \& Scarcella, R. (1992). The tapestry of language learning: the individual in the communicative classroom. Boston: Heinle \& Heinle Publishers.

Öz, H., Demirezen, M., \& Pourfeiz, J. (2015). Willingness to communicate of EFL learners in Turkish context. Learning and Individual Differences, 37(3), 269-275.

Park, G.)1997(. Language Learning Strategies and English Proficiency in Korean University Students. Foreign Language Annals 30(2), 211-21

Purpura, J. E. (1999). Learner strategy use and performance on language tests: A structural equation modeling approach. Cambridge: Cambridge University Press.

Rahbar, B., Suzani, M., \& Sajadi, Z. (2016). The relationship between emotional intelligence and willingness to communicate among Iranian intermediate EFL learners. Journal of Language Teaching: Theory and Practice, 2(3), 10-17.

Rashtchi, M., Khani, P. (2010). Improving EFL learner's oral proficiency through metacognitive strategy instruction. JELS, 1(4), 137-156.

Rasouli, M., Mollakhan, K., \& Karbalaei, A. (2013). The effect of metacognitive listening strategy training on listening comprehension in Iranian EFL context. European Online Journal of Natural and Social Sciences, 2(1), 115-128.

Sakai, H., \& Kikuchi, k. (2009). An analysis of demotivates in the EFL classroom. System, 37(1), 57-69.

Schroeder, R. (2016). The Development and Validation of the Academic Spoken English Strategies Survey (ASESS) for Non-native English Speaking Graduate Students. Journal of International Students, 2(4), 394-414.

Swain, M. (2000). The output hypothesis and beyond: Mediating acquisition through collaborative dialogue. In J. P. Lantolf (Ed.), sociocultural theory and second language learning (pp. 97-114). Oxford: Oxford University Press. 
Swain, M., \& Lapkin, S. (2002). Talking it through: Two French immersion learners' response to reformulation. International Journal of Educational Research, 37(3), 285-304.

Valadi, A., Rezaee, A., \& Kogani, P. (2015). The Relationship between Language Learners' Willingness to Communicate and Their Oral Language Proficiency with Regard to Gender Differences. International Journal of Applied Linguistics \& English Literature, 4(5), 147-153.

Vandergrift, L. (1997). The Cinderella of communication strategies: Reception strategies in interactive listening. The Modern Language Journal, 81(5), 495-505.

Wen, W. P., \& Clement, R. (2003) A Chinese conceptualization of willingness to communicate in ESL. Language, Culture and Curriculum, 16(1) (2003), 18-38.
Yang, S. (2009). Using blogs to enhance critical reflection and community of practice. Educational Technology \& Society, 12(2), 11-21.

Yousefi, M., \& Kasaian, S. A. (2014). Relationship between willingness to communicate and Iranian EFL learner's speaking fluency and accuracy. Journal of Advances in English Language Teaching; 2(6), 61-72.

Zare, P. (2012). Language learning strategies among EFL/ ESL learners: A review of literature. International Journal of Humanities and Social Science, 2(5), 162-169.

Zarei, A. A., \& Gilanian, M. (2015). Self-efficacy as a function of language learning. British Journal of Education, Society \& Behavioural Science, 9(3), 223-235.

Zarrinabadi, Z. (2014). Communicating in a second language: Investigating theEffect of Teacher on Learners' Willingness to Communicate, System, 42(1), 288-295. 